\title{
The reproductive ecology of the Antarctic bivalve Aequiyoldia eightsii (Protobranchia: Sareptidae) follows neither Antarctic nor taxonomic patterns
}

\author{
Sally C. Y. Lau ${ }^{1} \cdot$ Laura J. Grange $^{1} \cdot$ Lloyd S. Peck $^{2} \cdot$ Adam J. Reed $^{1}$
}

Received: 14 September 2017 / Revised: 9 March 2018 / Accepted: 13 March 2018 / Published online: 27 March 2018

(c) The Author(s) 2018

\begin{abstract}
The accepted paradigm for reproduction in Antarctic marine species is one where oogenesis takes 18 months to 2 years, and a bimodal egg-size distribution where two cohorts of eggs are present in female gonads throughout the year. These slow gametogenic traits are driven by low temperature and/or the restriction of resource availability because of extreme seasonality in the marine environment. Here we present data on the reproductive ecology of the common Antarctic bivalve Aequiyoldia eightsii (Jay, 1839) (Protobranchia: Sarepidae) from monthly samples collected between January 2013 and May 2014 at Hangar Cove, Rothera Point on the West Antarctic Peninsula. These data show that A. eightsii is unusual because it does not follow the typical pattern expected for reproduction in Antarctic marine invertebrates, and differs also from closely related nuculanid protobranch bivalves with respect to gametogenic duration and reproductive periodicity. Continuous oogenesis, evidenced by the year-round occurrence of previtellogenic, vitellogenic, and ripe oocytes in female gonads, is supplemented by a seasonal increase in reproductive intensity and spawning in Austral winter (April-May), evidenced by the loss of mature spermatozoa and ripe oocytes from males and females, respectively. The simultaneous occurrence of these contrasting traits in individuals is attributed to a flexible feeding strategy (suspension and deposit feeding) in response to seasonal changes in food supply characteristic of the Antarctic marine environment. Asynchrony between individual females is also notable. We hypothesise that the variability may represent a trade-off between somatic and reproductive growth, and previously reported internal interannual cycles in shell growth.
\end{abstract}

Keywords Antarctic $\cdot$ Marine $\cdot$ Invertebrate $\cdot$ Bivalve $\cdot$ Interannual $\cdot$ Reproduction

\section{Introduction}

Marine invertebrate reproductive ecology influences patterns of species biogeography, population persistence, and species survival (Ramirez-Llodra 2002; Lester et al. 2007).

Electronic supplementary material The online version of this article (https://doi.org/10.1007/s00300-018-2309-2) contains supplementary material, which is available to authorised users.

Adam J. Reed

ajr104@soton.ac.uk

1 Ocean and Earth Science, National Oceanography Centre Southampton, University of Southampton, European Way, Southampton SO14 3ZH, UK

2 British Antarctic Survey, Natural Environment Research Council, High Cross, Madingley Road, Cambridge CB3 0ET, UK
Investigating the reproduction of a particular species therefore provides insight into its adaptive capacity and potential resilience to environmental change (Byrne 2011; Sanford and Kelly 2011). As the global ocean is under increasing threat from climate change, especially warming and acidification (Byrne 2011), evaluation of a species' reproductive success is key to understanding vulnerability to future climate scenarios (Grange et al. 2004). In the Southern Ocean, the waters around the West Antarctic Peninsula have experienced pronounced warming relative to the global average (see review by Mayewski et al. 2009), with sea surface summer temperatures in the Bellingshausen Sea on the west of the Peninsula increasing by $\sim 1{ }^{\circ} \mathrm{C}$ since the 1950s (Meredith and King 2005). Antarctic shallow-water invertebrates are particularly susceptible to the effects of climate change, as warming causes perturbations in sea ice dynamics, which could subsequently lead to ecological regime shifts in benthic systems (Barnes and Conlan 2007; Barnes and Souster 
2011; Barnes 2016). Presently, there is a lack of knowledge specific to the recovery potential of the benthos after these disturbance events (Clark et al. 2015). Additionally, many studies have demonstrated the physiological constraints and vulnerability of Antarctic benthic invertebrates to subtle temperature increases (e.g. Peck et al. 2004a; Pörtner et al. 2007; Peck et al. 2010, 2014). Benthic assemblages in Antarctica are taxonomically diverse and abundant, with more than 7137 species identified, which accounts for $88 \%$ of the total number of identified species in the Southern Ocean (De Broyer and Danis 2011). However, the reproductive ecology and related paradigms regarding invertebrate life history and ecology are far from fully understood (Pearse and Lockhart 2004), with details of reproductive biology, especially in terms of variations between the years, or longer term trends, rarely published.

The reproductive patterns of Antarctic shallow-water benthos are often characterised by a prolonged reproductive cycle (18-24 months), lecithotrophy, and direct development, low fecundity, and seasonal reproductive patterns (Clarke 1979; Brey and Hain 1992; Chiantore et al. 2002; Grange et al. 2004, 2007; Higgs et al. 2009; Pearse et al. 2009; Reed et al. 2013a). However, a few species also demonstrate shorter gametogenic periods (12 months or less) (Clarke 1988; Chiantore et al. 2002; Tyler et al. 2003; Grange et al. 2011), planktotrophic larvae (Stanwell-Smith et al. 1999; Bowden et al. 2009), and relatively high fecundity (McClintock and Pearse 1986; Bosch and Pearse 1990; Grange et al. 2004; Orejas et al. 2007). Moreover, the reproductive ecology of Antarctic shallow-water and deep-sea species are similar in several benthic taxa, including asteroids (Bosch and Pearse 1990) and octocorals (Orejas et al. 2012). Several authors have suggested that the abiotic and biotic characteristics shared between the polar and deep-sea environments attribute similarities in reproductive ecology between Antarctic shallow-water and the deep-sea benthos (Bosch and Pearse 1990; Ramirez-Llodra 2002; Orejas et al. 2012). Both realms are characterised by low stable temperatures, low light, and ice scour, and functionally similar benthic communities with slow population turnover rates (Bosch and Pearse 1990; Aronson et al. 2007; Clark et al. 2015). Furthermore, the continental shelf in Antarctica is depressed by the weight of the ice-sheet, such that its average depth is around $500 \mathrm{~m}$ compared to around $200 \mathrm{~m}$ elsewhere in the world (Heywood et al. 2014). This feature facilitates the connection between shallow and deep areas of the Southern Ocean across the continental shelf, with submerging Antarctic bottom water and emerging circumpolar deep water that may have enhanced colonisation of shallow fauna to deep waters (and vice versa) during glacial cycles of shelf ice advance and retreat (Berkman et al. 2004; Strugnell et al. 2011). Many Antarctic invertebrate taxa including Bivalvia, Gastropoda, Amphipoda, and Decapoda are reported to have a significantly higher degree of eurybathy compared to their temperate counterparts, often being distributed from surface water to hundreds of metres (Brey et al. 1996).

Protobranchia is a subclass of small deposit feeding bivalves commonly found in soft sediment environments with approximately 750 species distributed globally (see review by Zardus 2002). With a Cambrian origin (Carter et al. 2000; Sharma et al. 2013), this subclass has diversified and colonised the deep sea, representing $\sim 50$ and $90 \%$ of bivalve species on the continental slope and abyssal plain, respectively (Allen 1978). Although protobranch bivalves are important bioturbators in the deep sea (Zardus 2002), they remain one of the least studied molluscan groups (Sharma et al. 2013; Reed et al. 2014). Protobranch bivalves are well represented in the Antarctic, but information regarding the ecology of Protobranchia in the Southern Ocean is limited as most species are found only in deeper water (Reed et al. 2013b). One exception is the common shallow-water species Aequiyoldia eightsii (Jay, 1939) (previously Yoldia eightsii), which has been used as a model bivalve species in several investigations. While studies have examined its abundance and ecophysiology (described below), the reproductive ecology and gametogenic cycles in this species are poorly understood, constrained by the problems associated with seasonal sampling of organisms in the Southern Ocean.

Here, we investigated the reproductive ecology of an Antarctic shallow-water protobranch bivalve $A$. eightsii, which is one of the most abundant benthic species in the maritime Antarctic. Previous records show densities of A. eightsii of up to $1540 \mathrm{~m}^{-2}$ at Signy Island (Peck and Bullough 1993) and biomass contributions equivalent to $56.6 \%$ of the total macrofaunal biomass at Faro station in Potter Cove (Pasotti et al. 2015a). The geographical distribution of A. eightsii is patchy around the Antarctic continent (Dell 1990), but is extended to sub-Antarctic regions including King George Island $\left(62^{\circ} 10^{\prime} \mathrm{S}\right)$ and the Magellan Strait $\left(53^{\circ}\right.$ 28'S) (González-Wevar et al. 2012). With a bathymetric distribution ranging from intertidal sand flats to deep waters (824 m), A. eightsii is most commonly found at depths shallower than 100 m (Dell 1990; Peck and Bullough 1993). Aequiyoldia eightsii has an opportunistic feeding strategy, which typically exhibits deposit feeding but can alternate to a suspension feeding mode when phytoplankton is present in the water column (Davenport 1988). Deposit feeding and burrowing in A. eightsii involve intensive locomotion, where this species is one of the fastest burrowing of all Antarctic marine benthic groups (Peck et al. 2004b). Previous observations have also shown a single specimen can expel sediment up to 13 times its dry tissue mass within $24 \mathrm{~h}$ (Davenport 1988). Given its high abundance and wide distribution within Antarctica, A. eightsii is likely to be one of the major bioturbators among the Antarctic shallow-water benthic communities. Moreover, A. eightsii has frequently 
featured in physiological studies as a comparative species with other Antarctic benthos (Peck and Conway 2000; Peck et al. 2004b; Fattorini et al. 2010; Peck et al. 2014; RománGonzález et al. 2017), and as a model species in studies designed to analyse the impact of climate change on Antarctic seafloor communities (McClintock et al. 2009; Peck et al. 2009, 2010; Clark et al. 2016). A recent study identified an innate endogenous growth rhythm in this species and suggested the pattern may be attributed to the reallocation of energy resources between cycles of somatic and reproductive investment (Román-González et al. 2017). Owing to the use of A. eightsii in a range of Antarctic ecological studies, the reproductive data reported here should inform future studies focused on interpreting the biological and ecological role of the species, and the ecological processes of the Protobranchia and Antarctic benthos as a whole.

The objectives of this study were to (1) describe the reproductive ecology and general anatomy of A. eightsii from a shallow-water site at Rothera Point off the West Antarctic Peninsula using wax histology, (2) to compare the reproductive condition of $A$. eightsii with other Antarctic shallow-water benthos and protobranch bivalves, and (3) to evaluate, where possible, what may be driving these reproductive patterns.

\section{Materials and methods}

\section{Sample collection}

Monthly samples of A. eightsii were scuba diver-collected between January 2013 and May 2014 at 13 to $16 \mathrm{~m}$ depths in Hangar Cove, adjacent to the British Antarctic Survey's Rothera Research Station on Rothera Point, Adelaide Island, off the West Antarctic Peninsula $\left(67^{\circ} 33^{\prime} 52 \mathrm{~S}, 68^{\circ} 07^{\prime} 43 \mathrm{~W}\right)$ (Fig. 1). Fifteen to 20 individuals were collected per month and fixed in $4 \%$ buffered formaldehyde in the field. Formaldehyde-preserved samples were then transported to the University of Southampton, UK for storage. Poor ice conditions and inclement weather prevented field sampling in February and June 2013.

\section{Histological preparation}

For each specimen, maximum shell length, height, and width were measured using a digital calliper $( \pm 0.01 \mathrm{~mm})$ and the soft tissue separated from the shell using a scalpel. Photographs of specimens before and after shell removal were taken for anatomical study.
Fig. 1 Location of sampling site for Aequiyoldia eightsii in Hangar Cove, Adelaide Island, West Antarctic Peninsula $\left(67^{\circ} 33^{\prime} 52 \mathrm{~S}, 68^{\circ} 07^{\prime} 43 \mathrm{~W}\right)$

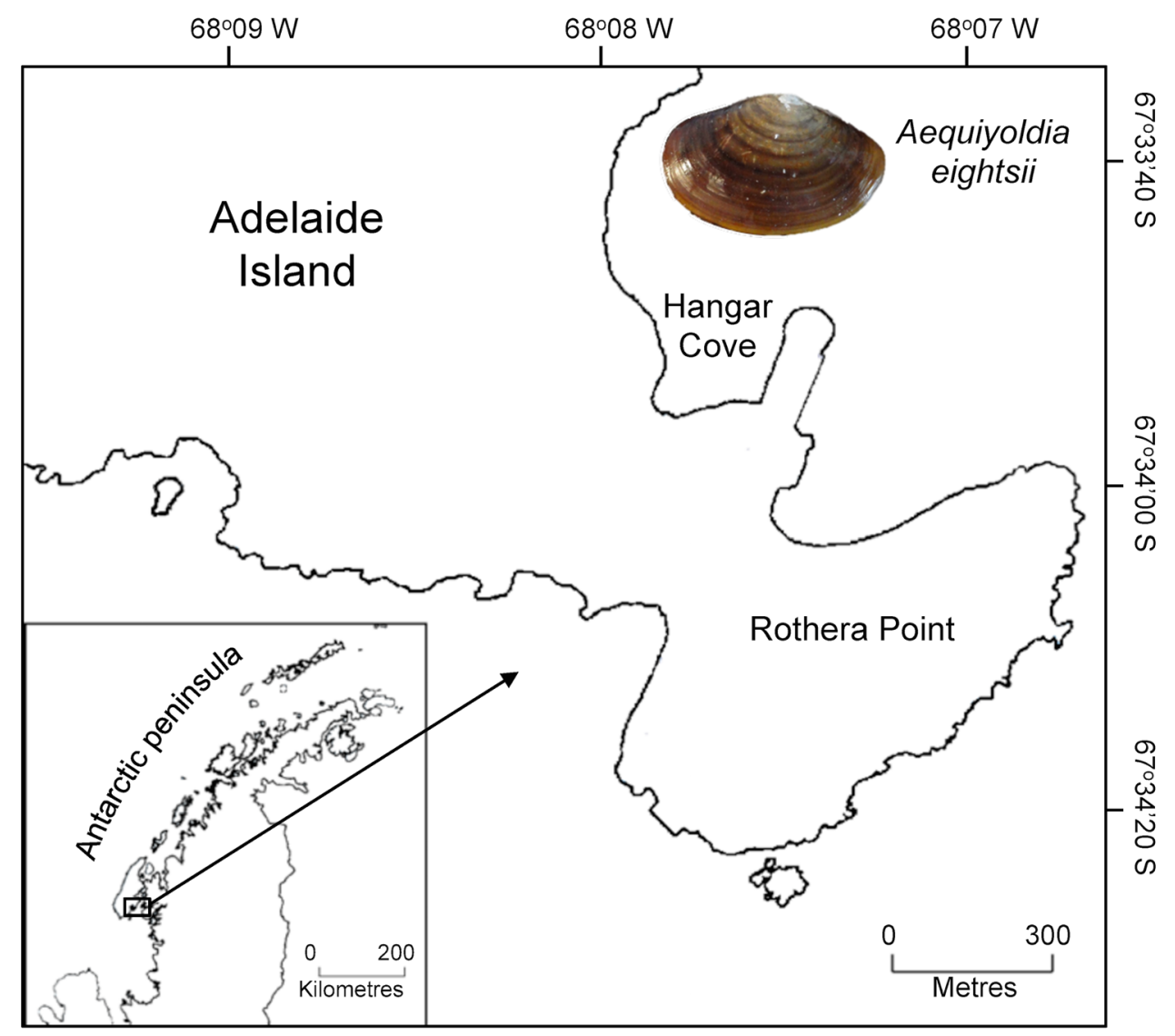


Aequiyoldia eightsii with shell length $>20 \mathrm{~mm}$ have been reported to be reproductively mature (Peck et al. 2000). In an effort to maintain consistency, only individuals with a shell length between 20 and $25 \mathrm{~mm}$ were selected for processing. None of the bivalves collected in March or August 2013 measured between 20 and $25 \mathrm{~mm}$ and were therefore discounted from further study. A total of 95 individuals were selected for histological analysis. Sex of individuals was determined from histological sections.

The gonad of A. eightsii is not a discrete organ and the germinal tissues are infiltrated in the visceral mass. Therefore, whole specimens were examined using standard wax histology techniques following the protocol outlined in Higgs et al. (2009). Preliminary studies demonstrated the denser foot muscle to be more sensitive to the process of clearing when compared to other soft tissues. This tissue was therefore dissected and processed separately. Bivalves were dissected in a longitudinal direction through the body just below the digestive gland, removing the foot muscle from the main body.

Both dissected parts of soft tissue were dehydrated in a graded series of isopropanol, cleared in three washes of histoclear (CellPath, UK) and embedded in wax blocks. Serial sections of $7 \mu \mathrm{m}$ thick were mounted and stained with Haematoxylin Z (CellPath, UK) and Eosin Y (CellPath, UK), and immediately cover-slipped using a DPX mounting medium (Sigma-Aldrich, UK). Note that the gonads of six female individuals were damaged during histological preparation and were therefore excluded from reproductive analysis.

\section{Data analysis}

\section{Gonad morphology}

General anatomical observations of A. eightsii were made with respect to gonad morphology from the serial sectioning of both dissected parts of animals under a light microscope [Olympus BHS (BH-2)], and the macrophotography images of soft tissues after shell removal.

\section{Female reproductive analysis}

Preliminary analysis indicated that a sexually mature female could simultaneously carry in excess of 3000 oocytes. Therefore, only eight histological sections, evenly distributed across the gonad-digestive complex per specimen (around $1.5 \mathrm{~mm}$ apart), were taken for image analysis. Thin tissue sections were photographed using a Nikon D5000 digital camera mounted on a light microscope [Olympus BHS (BH-2)]. Oocyte size, measured as Equivalent Circular Diameter (ECD), of individual females was quantified using the 'Area' tool in ImageJ v1.48 (Rasband 1997-2016).
ECD assumes the best-fit spherical size of each oocyte and is equivalent to Oocyte Feret Diameter (OFD) used in previous studies (e.g. Reed et al. 2013a, 2014). Only oocytes with a visible nucleus were measured to ensure the size of each oocyte was approximated at, or very close to its maximum cross-sectional area. The equation used for calculating ECD from the traced area of each oocyte was

$\mathrm{ECD}=2 \sqrt{\frac{A}{\pi}}$

where ECD is Equivalent Circular Diameter $(\mu \mathrm{m})$, and $A$ is the area of an individual oocyte $\left(\mu \mathrm{m}^{2}\right)$.

Female maturity was evaluated based on the overall oocyte cellular appearance and description of marine bivalve ovary development outlined in Morse and Zardus (1997). Oocytes $<50 \mu \mathrm{m}$ ECD, with basophilic cytoplasm and a large nucleus, were defined as previtellogenic. Oocytes between 50 and $80 \mu \mathrm{m} \mathrm{ECD,} \mathrm{with} \mathrm{eosinophilic}$ cytoplasm and yolk droplets, were identified as vitellogenic, whereas oocytes $>80 \mu \mathrm{m}$ ECD with an outer vitelline envelope and jelly coat were defined as ripe oocytes (Fig. 1 in Online Resource 1).

\section{Male reproductive analysis}

Eight histological sections evenly distributed across the gonad-digestive complex of each male A. eightsii were photographed for image analysis. Five stages of gonad maturity were identified according to the rationale for the overall development and distribution of spermatozoa in marine bivalve testes development described in Morse and Zardus (1997) (Fig. 2 in Online Resource 1).

Stage I (early developing stage) Spermatogonia develop along the follicle wall.

Stage II (mid-developing stage) Spermatogonia divide into spermatocytes and move away from the follicle wall. The spermatocytes have increased in number and occur in clusters.

Stage III (late developing stage) Spermatocytes divide into spermatids, which then differentiate into spermatozoa. The division and differentiation process leads to spermatozoa being placed in the centre of the lumen in chained form. 
Stage IV (ripe stage)

Stage V (spent stage)
Spermatozoa increase in number and occupy the entire lumen. Testes expand in size and are fully developed.

Spawned spermatozoa; testes are reduced in size with empty spaces visible in follicles.

\section{Statistical analysis}

A $\chi^{2}$ test of independence was conducted between both month using pooled females and individual females within each month, and oocyte size frequency distribution to determine whether there was a statistically significant association between these variables. For instances, where expected cell frequencies were less than five, neighbouring oocyte size bin ranges were collapsed and the procedure re-run until this assumption was met. Statistical significance is reported at $p<0.05$. For instances, where a statistically significant association was reported, the strength of association between variables was evaluated using Cramer's $V$ (Cohen 1988), with a value of 0 and 1 indicating "no association" and "complete association", respectively (i.e. small association $=0.1$, moderate association $=0.3$, and large association $=0.5$ ). In addition, the deviation of individual cells from independence was reported using adjusted standardised residuals according to Agresti (2007), where values $>3$ were deemed indicative of cells that significantly deviate from independence.

All statistical analyses were performed using IBM SPSS Statistics version 24 for Mac OS X.

\section{Results}

\section{Gonad morphology}

The overall anatomy of A. eightsii is presented in Fig. 2 . The gonad envelops the centre of the alimentary canal. A thin layer of gonadal tissue (up to 3-4 cells thick) covers the outer layer of the digestive gland and envelops the stomach where the gonad tissue thins to approximately 1 cell thick. A strip of gonadal cells is located within the anterior adductor in the upper body (Figs. 2b,d; 3a).

While the diameter of the stomach reduces as it penetrates the centre of the foot muscle, the gonadal tissue layer around the stomach thickens (up to 10-12 cells thick; Fig. 3b). The adjacent section of hindgut in the foot muscle is also surrounded by gonadal tissue, but fewer cells are present (around 5-6 cells thick). No gonadal cells are found near the base of the half gut loop in the foot muscle.

\section{Sex ratio}

All specimens $(n=95)$ selected for histological analysis had distinguishable gonads and were separately sexed. Of the 95 individuals, 48 (50.5\%) were female and 47 (49.5\%) were male.

\section{Female reproductive analysis}

Qualitative assessment of the female gonad revealed the presence of oocytes of all developing stages throughout the study period. Previtellogenic oocytes (and other smaller
Fig. 2 Anatomy of a female Aequiyoldia eightsii collected in April 2013 from Hangar Cove, Adelaide Island, West Antarctic Peninsula $\left(67^{\circ} 33^{\prime} 52 \mathrm{~S}\right.$, $\left.68^{\circ} 07^{\prime} 43 \mathrm{~W}\right)$. a Photograph of soft tissue after shell removal (left side); b General anatomical structure (left side). Gonad envelopes $d g$ digestive gland shown in orange; $\mathbf{c}$ Photograph of soft tissue after shell removal (right side). d Configuration of the alimentary canal and associated gonad (right side). $a$ anus, $a a$ anterior adductor, $d g$ digestive gland, es exhalent siphon, $f$ foot, $c t$ ctenidium, $h$ hinge, $h g$ hindgut, is inhalant siphon, $o$ oesophagus (attaches to $p l$ ), $p a$ posterior adductor, $p l$ palp lamella, $p p$ palp proboscid, $r$ rectum, st stomach. Scale bar $1 \mathrm{~cm}$
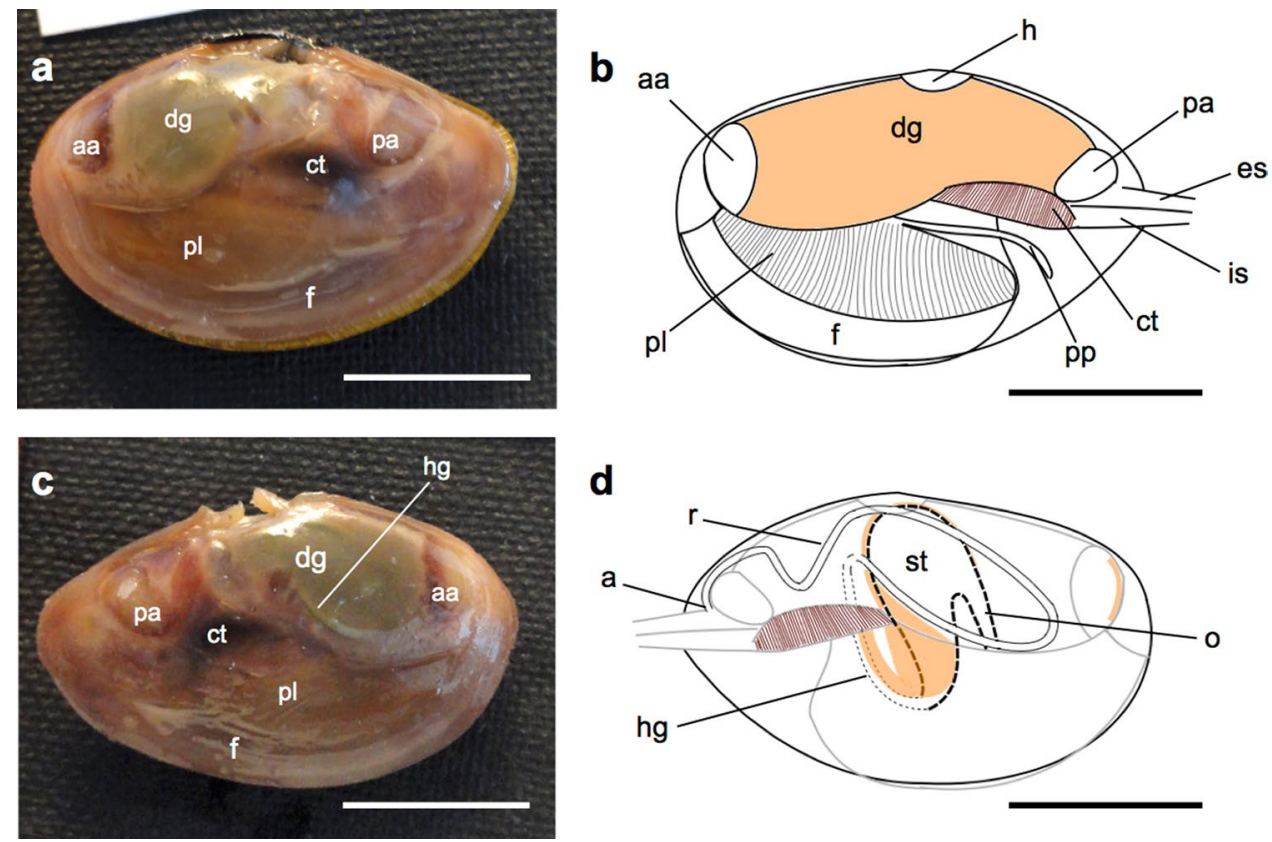


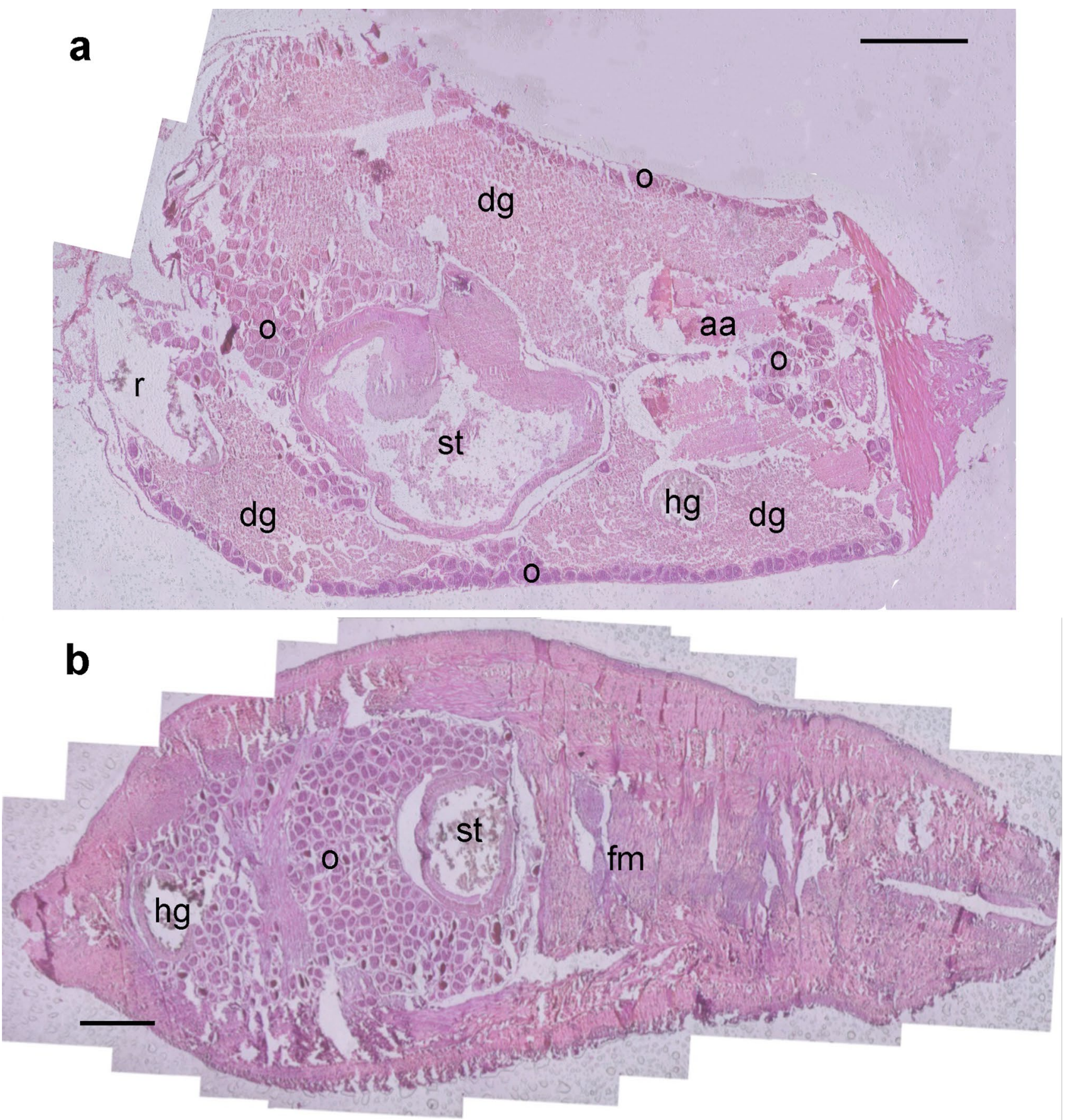

Fig. 3 Transverse histological sections of a female Aequiyoldia eightsii collected in April 2013 at Hangar Cove, Adelaide Island, West Antarctic Peninsula $\left(67^{\circ} 33^{\prime} 52 \mathrm{~S}, 68^{\circ} 07^{\prime} 43 \mathrm{~W}\right)$. a Horizontal section

oocytes) were observed developing along the follicle walls next to both vitellogenic and ripe oocytes throughout all months, and in 39 of the 42 females sampled between January 2013 and May 2014 (Fig. 4). The absence of ripe oocytes was observed in the gonad of only three females, comprising single specimens from July 2013 (shell length $=20.95 \mathrm{~mm}$ ), through the median level of the visceral mass. b Horizontal section through the top level of foot muscle. $f m$ foot muscle, $o$ oocytes. Scale bar $500 \mu \mathrm{m}$. For other abbreviations see Fig. 2

October 2013 (shell length $=20.40 \mathrm{~mm}$ ), and May 2014 ( shell length $=24.62 \mathrm{~mm}$ ). The measured oocyte diameters ranged from 12.5 to $176.7 \mu \mathrm{m}$. A spawning event occurred between April and May in 2013 and 2014, indicated by a reduction in average oocyte size $( \pm$ SD), from $97.4 \pm 23.4 \mu \mathrm{m}, n=3549$ to $59.3 \pm 14.3 \mu \mathrm{m}, n=740$, and 
Fig. 4 Oocyte ripening in Aequiyoldia eightsii from Hangar Cove, Adelaide Island, West Antarctic Peninsula $\left(67^{\circ} 33^{\prime} 52 \mathrm{~S}, 68^{\circ} 07^{\prime} 43 \mathrm{~W}\right)$ between January 2013 and May 2014. DG digestive gland, $H G$ hindgut, $M O$ ripe oocytes, $O G$ oogonia, $P V O$ previtellogenic oocytes, $V O$ vitellogenic oocytes. Scale bar $200 \mu \mathrm{m}$
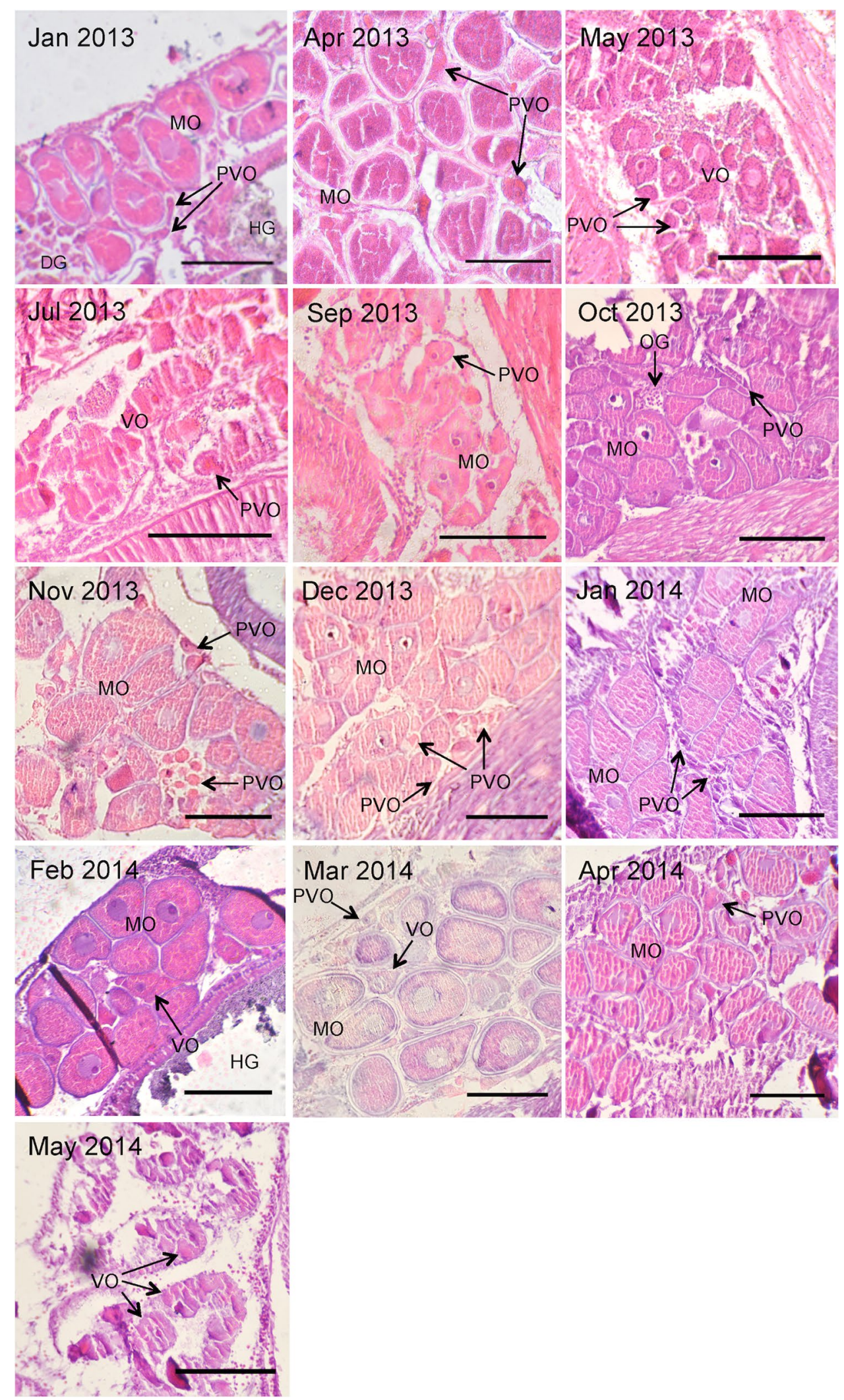
from $93.0 \pm 28.7 \mu \mathrm{m}, n=2164$ to $54.2 \pm 14.5 \mu \mathrm{m}, n=208$, respectively.

Although oocytes of all maturity stages were observed in the gonad throughout the study period, the distribution of oocyte sizes varied between months (Fig. 5). A $\chi^{2}$ test of independence was conducted between month, using pooled females, and oocyte size frequency distribution. All expected cell frequencies were greater than five. There was a statistically significant association between month and the frequencies of oocytes distributed across the range of oocyte size $\left(\chi^{2}\right.$ $=8156.288, \mathrm{df}=36, p<0.0001)$. The association was moderately strong (Cohen, 1988), Cramer's $V=0.349$, and 46 of 52 cells had adjusted standardised residuals $>3$ (Table 1) indicating a significant deviation from independence.

Statistically significant associations between individual females, sampled in the same month, and their oocyte size frequency distributions were also recorded, where the strength of associations was generally moderate $(p<0.05$; see Table 1 in Online Resource 2).

\section{Male reproductive analysis}

Seasonal changes in male maturity stage were interpreted to show a spawning event in April-May, as indicated by spent testicular acini (stage V) in 2013 and newly developed spermatogonia (stage I) in 2014 (Fig. 6). Testes matured from an early developmental (stage I) to mature stage (stage IV) between July 2013 and April 2014, and from a late developmental (stage III) to mature stage (stage IV) between January and April 2013.

\section{Discussion}

The present study of the reproductive ecology of the Antarctic shallow-water protobranch bivalve, A. eightsii, demonstrates a reproductive mode that differs from previously described protobranch species and other Antarctic shallowwater invertebrates. Our results indicate that the Hangar Cove population of A. eightsii exhibits continuous oogenesis, with a period of increased reproductive intensity and spawning between April and May, with asynchrony in oocyte development among females. Although we acknowledge reduced sample sizes in some months, this was to ensure all samples were comparable with respect to shell lengths and therefore sexual maturity, based on previous studies (Peck et al. 2010). Of those specimens which fit our selection criteria, there was no control over gender at the point of collection. Within the individual females measured, efforts were made to measure in excess of 1000 oocytes where possible to reduce the weighting of inherent variability. All specimens in this study were dioecious with an overall female-to-male ratio approximating unity and with no evidence of hermaphroditism found.

Continuous investment in oogenesis was evidenced by the simultaneous, year-round occurrence of previtellogenic, vitellogenic, and ripe oocytes in the female gonads. This reproductive trait contrasts with observations of seasonal oogenic development reported in most shallow-water Antarctic marine invertebrates studied to date (e.g. Chiantore et al. 2001; Ahn et al. 2003; Tyler et al. 2003; Grange et al. 2004, 2007; Kang et al. 2009; Grange et al. 2011; Reed et al. $2013 \mathrm{a}, \mathrm{b})$, and other closely related protobranch bivalves including the cold water Yoldia hyperborea (Jaramillo and Thompson 2008), where cohorts of oocytes distinguishable in their maturity stage dominate the gonad at different times of year. Continuous oogenesis is observed, however, in some deep-sea protobranch bivalves (Tyler et al. 1992; Zardus 2002; Scheltema and Williams 2009; Reed et al. 2014). Significant associations between individual females and their oocyte size frequency distribution were also observed indicating asynchrony in oogenesis between individuals sampled in the same month. This asynchrony could be attributed to an aseasonal reproductive rhythm. However, we did not observe any evidence for aseasonality in the form of multiple spawning events in the females (Fig. 6), nor male maturity stage (Fig. 2 in Online Resource 1). Instead, we observed a seasonal periodicity in the reproduction of both male and female A. eightsii (described below). In the case of the females studied, this seasonal periodicity was observed simultaneously to the continuous investment in oocyte development described above. We therefore propose that the asynchrony observed between individual females is consistent with an innate, long-term multi-year reproductive cycle, related to the partitioning of energetic resources between somatic and reproductive investment (as hypothesised in Román-González et al. 2017 and discussed below).

Observed simultaneously to the continuous oocyte development described above was a seasonal increase in reproductive intensity (spawning) during early Austral winter. This was demonstrated by an investment in the size and presence of ripe oocytes and their subsequent loss from the gonad, and a statistically significant association between month and oocyte size frequency distribution. Despite this observation, previous studies have identified very few bivalve veligers or larvae in winter in shallow waters adjacent to Rothera Research Station (Bowden et al. 2009). However, the pericalymma larva of protobranchs differs from the typical veliger larva of most bivalves in identifying features, being barrel-shaped and cloaked with an outer test enveloping the larva (Zardus and Morse 1998). This atypical appearance and the well-established difficulties associated with field identification of larvae render this larval type susceptible to misidentification, underestimation, and/or being missed entirely in plankton samples. Winter spawning events have 

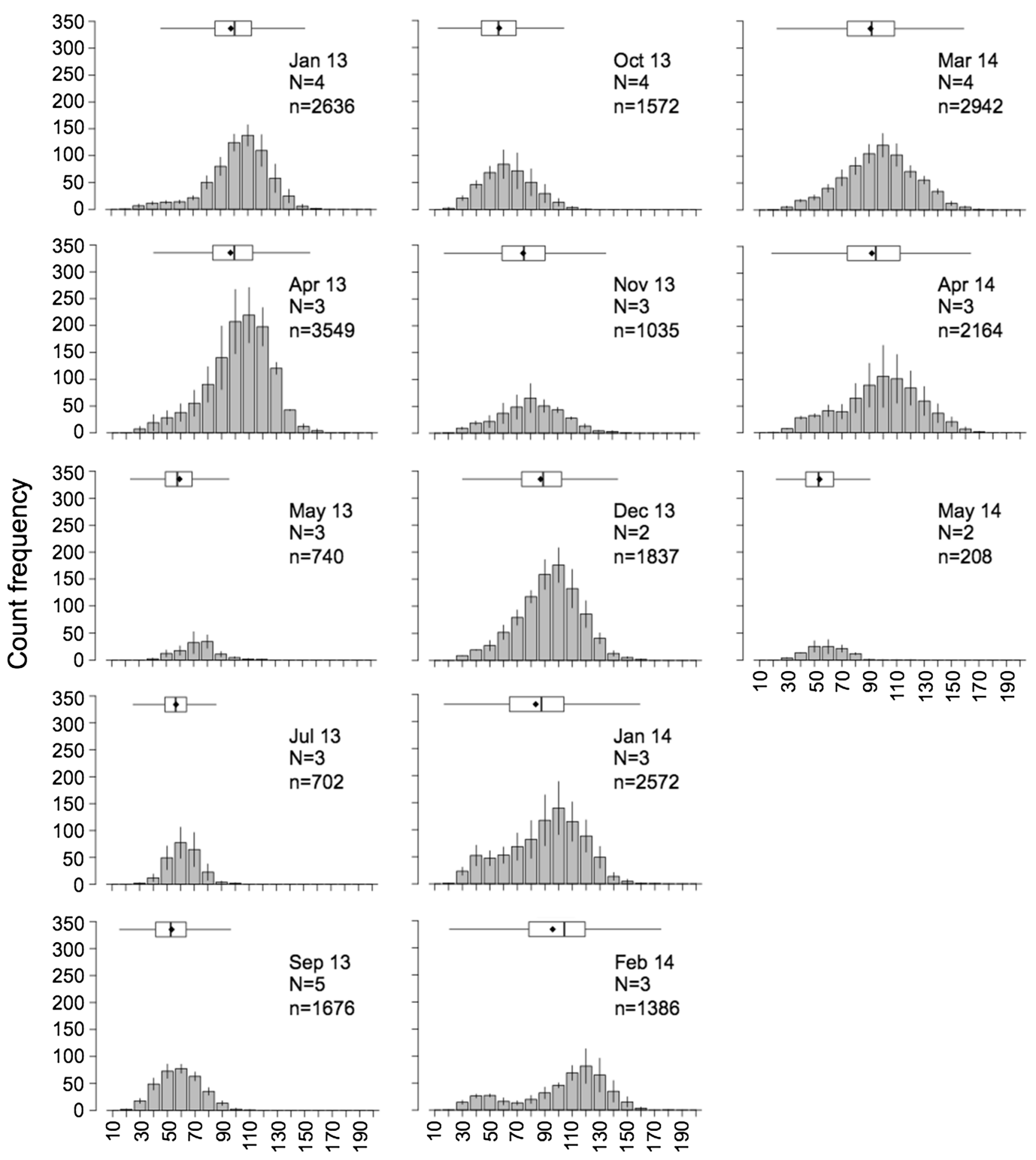

\section{Oocyte size $(\mu \mathrm{m})$}

Fig. 5 Average monthly oocyte size frequency distributions measured as Equivalent Circular Diameter $(\mu \mathrm{m})$ of Aequiyoldia eightsii from Hangar Cove, Adelaide Island, West Antarctic Peninsula (67 33 52S, $68^{\circ} 07^{\prime} 43 \mathrm{~W}$ ) between January 2013 and May 2014. Box-whisker plots for each month; diamond mean, line median, box 25th to 75th percentile range, and whiskers 1.5 times the value of the interquartile range. Oocyte diameter equivalent circular diameter. $N$ number of females, $n$ number of oocytes measured. Error bars $\pm 1 \mathrm{SE}$ 
Table 1 Cross tabulation of month, using pooled females of Aequiyoldia eightsi, and oocyte size frequency distribution

\begin{tabular}{|c|c|c|c|c|c|c|c|c|c|c|c|c|c|}
\hline \multirow[t]{3}{*}{ Oocyte size $(\mu \mathrm{m})$} & \multicolumn{13}{|l|}{ Month } \\
\hline & \multicolumn{8}{|l|}{2013} & \multicolumn{5}{|l|}{2014} \\
\hline & Jan & Apr & May & Jul & Sep & Oct & Nov & Dec & Jan & Feb & Mar & Apr & May \\
\hline 0-40 & $\begin{array}{l}74 \\
{[-9.1]}\end{array}$ & $\begin{array}{l}80 \\
{[-\mathbf{1 2 . 2}]}\end{array}$ & $\begin{array}{l}47 \\
{[-0.8]}\end{array}$ & $\begin{array}{l}42 \\
{[-1.1]}\end{array}$ & $\begin{array}{l}346 \\
{[\mathbf{2 2 . 6}]}\end{array}$ & $\begin{array}{l}281 \\
{[\mathbf{1 7 . 4}]}\end{array}$ & $\begin{array}{l}87 \\
{[1.7]}\end{array}$ & $\begin{array}{l}57 \\
{[-6.9]}\end{array}$ & $\begin{array}{l}230 \\
{[4]}\end{array}$ & $\begin{array}{l}95 \\
{[6.1]}\end{array}$ & $\begin{array}{l}95 \\
{[-8.7]}\end{array}$ & $\begin{array}{l}110 \\
{[-3.8]}\end{array}$ & $\begin{array}{l}35 \\
{[5.5]}\end{array}$ \\
\hline $40-60$ & $\begin{array}{l}109 \\
{[\mathbf{- 1 8 . 2}]}\end{array}$ & $\begin{array}{l}199 \\
{[\mathbf{- 1 9}]}\end{array}$ & $\begin{array}{l}355 \\
{[\mathbf{2 3 . 5}]}\end{array}$ & $\begin{array}{l}380 \\
{[27.3]}\end{array}$ & $\begin{array}{l}751 \\
{[32.5]}\end{array}$ & $\begin{array}{l}610 \\
{[\mathbf{2 4 . 8}]}\end{array}$ & $\begin{array}{l}176 \\
{[0.5]}\end{array}$ & $\begin{array}{l}159 \\
{[-9.4]}\end{array}$ & $\begin{array}{l}301 \\
{[-6.9]}\end{array}$ & $\begin{array}{l}71 \\
{[-\mathbf{5 . 3}]}\end{array}$ & $\begin{array}{l}254 \\
{[\mathbf{- 1 2 . 3}]}\end{array}$ & $\begin{array}{l}221 \\
{[-\mathbf{8 . 3}]}\end{array}$ & $\begin{array}{l}101 \\
{[\mathbf{1 2 . 5}]}\end{array}$ \\
\hline $60-80$ & $\begin{array}{l}287 \\
{[\mathbf{- 1 2 . 4}]}\end{array}$ & $\begin{array}{l}437 \\
{[\mathbf{- 1 2 . 4}]}\end{array}$ & $\begin{array}{l}284 \\
{[\mathbf{1 2 . 8}]}\end{array}$ & $\begin{array}{l}262 \\
{[11.7]}\end{array}$ & $\begin{array}{l}493 \\
{[\mathbf{1 0 . 1}]}\end{array}$ & $\begin{array}{l}489 \\
{[\mathbf{1 1 . 5}]}\end{array}$ & $\begin{array}{l}342 \\
{[\mathbf{1 0 . 8}]}\end{array}$ & $\begin{array}{l}393 \\
{[1.6]}\end{array}$ & $\begin{array}{l}452 \\
{[\mathbf{- 3 . 2}]}\end{array}$ & $\begin{array}{l}75 \\
{[-7]}\end{array}$ & $\begin{array}{l}566 \\
{[-1]}\end{array}$ & $\begin{array}{l}314 \\
{[-6.6]}\end{array}$ & $\begin{array}{l}67 \\
{[4.5]}\end{array}$ \\
\hline 80-180 & $\begin{array}{l}2166 \\
{[\mathbf{2 8 . 3}}\end{array}$ & $\begin{array}{l}2833 \\
{[30.5]}\end{array}$ & $\begin{array}{l}54 \\
{[-27.5]}\end{array}$ & $\begin{array}{l}18 \\
{[-29.3]}\end{array}$ & $\begin{array}{l}86 \\
{[-\mathbf{4 4 . 1}]}\end{array}$ & $\begin{array}{l}192 \\
{[-\mathbf{3 6 . 8}]}\end{array}$ & $\begin{array}{l}430 \\
{[-\mathbf{1 0}]}\end{array}$ & $\begin{array}{l}1228 \\
{[9.3]}\end{array}$ & $\begin{array}{l}1589 \\
{[5.7]}\end{array}$ & $\begin{array}{l}511 \\
{[6.4]}\end{array}$ & $\begin{array}{l}2027 \\
{[\mathbf{1 4 . 5}]}\end{array}$ & $\begin{array}{l}1519 \\
{[\mathbf{1 3 . 5}]}\end{array}$ & $\begin{array}{l}5 \\
{[-\mathbf{1 5 . 8}]}\end{array}$ \\
\hline
\end{tabular}

Adjusted standardised residuals appear in parentheses below observed frequencies. Adjusted standardised residuals $>3$, i.e. where cells significantly deviate from independence, are indicated in bold

been previously reported for other Antarctic shallow benthic invertebrates, including the seastar Odontaster validus (Pearse 1965), the ascidian Cnemidocarpa verrucosa (Sahade et al. 2004), and the octocoral Malacobelemnon daytoni (Servetto and Sahade 2016), and confirmed in some cases by the presence of larval stages in the water column (e.g. for O. validus; Bowden et al. 2009). These events have been attributed to flexible feeding, energy storage, and/or extended gametogenic periods. In the case of A. eightsii, based on observations in this study, there is no evidence of energy storage or an extended gametogenic period; however, flexible feeding in the form of both suspension and deposit feeding has been reported (Davenport 1988), and we speculate that the peculiar reproductive ecology of the bivalve is underpinned by a long-term internal cycle related to energy allocation.

Feeding plasticity may overcome the food limitation that characterises shallow Antarctic waters and poses resource limits for many species during winter, and may also facilitate the continuous oogenesis observed in A. eightsii. Aequiyoldia eightsii exploits phytoplankton in the summer by suspension feeding, and deposit feeds on organic material in the sediment, mostly composed of microphytobenthos and macroalgal fragments all year round (Davenport 1988; Corbisier et al. 2004; Pasotti et al. 2015b). Fragments of phytoplankton/algae were observed in the stomach and hindgut of all specimens in the current study, supporting continuous feeding throughout the year. These findings are consistent with previous laboratory experiments where specimens aged younger than 24 years fed primarily on phytoplankton $<20 \mu \mathrm{m}$ in diameter (Cripps and Priddle 1995). As the A. eightsii specimens analysed in the current study had shell lengths between 20 and $25 \mathrm{~mm}$, representative of 10-33 years of age (Peck and Bullough 1993), it is likely that the phytobenthos is the primary food source. Nanoplankton concentrations in the waters around Rothera
Research Station peak in the late summer ( March), and are suggested to have an important influence on the ecology of benthic grazers in the area (Clarke et al. 2008). The settlement and subsequent deposit feeding on nanoplankton in sediment therefore could trigger a reproductive response in A. eightsii, such as spawning in the Hangar Cove population, which could explain the increased reproductive intensity and spawning detected in April and May.

While feeding plasticity enables $A$. eightsii to sustain continuous oogenesis, and the seasonal availability of food, i.e. nanoplankton production, acts as a selective pressure driving a superimposed seasonal reproduction, recent evidence of a multi-year cycle in shell growth of the protobranch bivalve (Román-González et al. 2017) suggests the reproductive asynchrony observed in females is not underpinned by environmental factors. Nor can this reproductive pattern be explained by the accepted paradigm of an 18to 24-month period needed for oogenesis in several other Antarctic invertebrates (Peck et al. 2005; for examples see Grange et al. 2004, 2007; Brockington et al. 2007; Orejas et al. 2007). The reproductive ecology of A. eightsii also differs from other shallow-water and deep-sea nuculanid protobranch bivalves that have a 12-month gametogenic cycle, often with seasonal investment in reproduction (Tyler et al. 1992; Nakaoka 1994; Jaramillo and Thompson 2008; Scheltema and Williams 2009). Instead the asynchrony observed here may be linked to an innate, endogenous growth rhythm (e.g. 9.06 year) that is asynchronous between individuals, not keyed with environmental variability, and attributable to cycles in reproductive output (Román-González et al. 2017).

The maximum egg size of $A$. eightsii measured in this study was $176.7 \mu \mathrm{m}$. In marine invertebrates, larval development mode is often inferred from egg size (Moran and McAlister 2009). However, in Protobranchia, egg sizes can vary extensively within individual modes of development and even within closely related species (Gustafson and Reid 1986; 

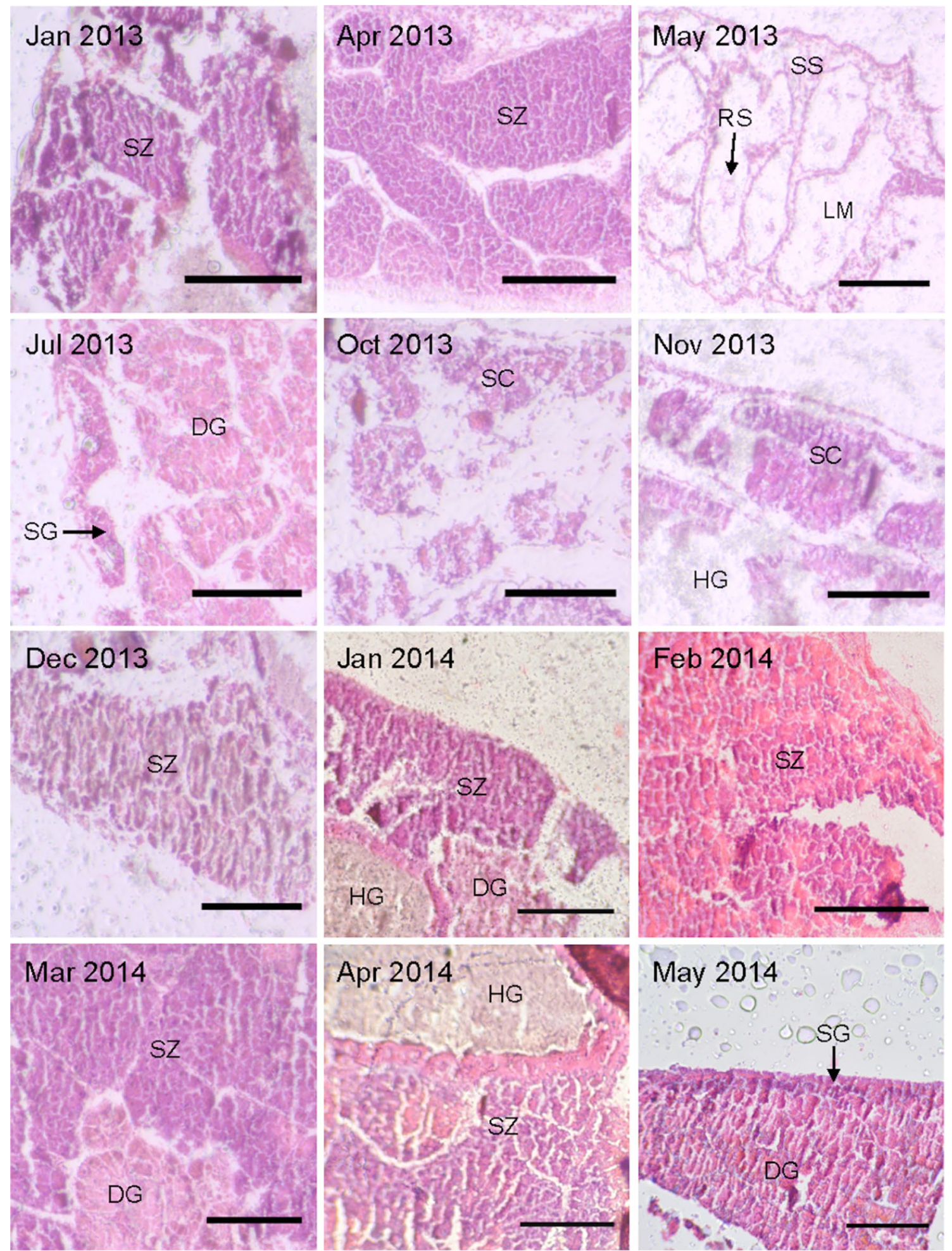

Fig. 6 Testes maturation in Aequiyoldia eightsii from Hangar Cove,

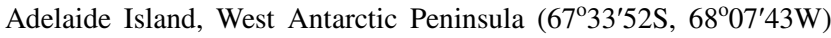
between January 2013 and May 2014. DG digestive gland, $H G$ hind- gut, $L M$ lumen, $R S$ residual sperm, $S C$ spermatocytes, $S G$ spermatogonia, $S S$ spent acini, $S Z$ spermatozoa. Scale bar $200 \mu \mathrm{m}$ 
Scheltema and Williams 2009). This subclass is known to only exhibit two modes of larval development to date: pelagic lecithotrophy and brooding (Zardus 2002; Scheltema and Williams 2009). Since gametogenesis of A. eightsii shows synchrony in seasonality between males and females, the loss of a relatively large proportion of gametes between April and May and the absence of brooded embryos suggest this bivalve is a broadcast spawner with lecithotrophic larvae. Winter spawning of lecithotrophic larvae may facilitate the avoidance of predators feeding on larvae associated with the summer bloom (Sahade et al. 2004), ice-mediated disturbance (Barnes and Souster 2011), and a greater availability of free substratum for larval settlement (Bowden 2005). As adult A. eightsii can inhibit larval settlement via density-dependent control (Peck and Bullough 1993), larvae spawned during periods with more available habitat could increase the chance of settlement.

The reproductive ecology of A. eightsii exhibits continuous oogenesis, with a period of increased reproductive intensity and spawning between April and May, and asynchrony between females. These characteristics contrast with the seasonal reproductive traits reported for many shallowwater Antarctic invertebrates and closely related protobranch bivalves. We hypothesise that the asynchrony documented between females is underpinned by a multi-year periodicity attributed to an innate, endogenous rhythm related to energetic allocation between somatic and reproductive investment. However, the ability to switch between suspension and deposit feeding modes, according to the quality and quantity of food available, facilitates a continuous investment into oogenesis, whilst being responsive to the seasonal pulse in primary production. This study provides key information on a scientifically important species of bivalve that has been commonly used for baseline ecological investigations in Antarctica. Knowledge of its reproduction provides insight into the biological flexibility of the species and contributes to our wider understanding of adaptations in polar marine environments.

Acknowledgements We thank the Natural Environment Research Council for support via core resources to the British Antarctic Survey. We also thank the Rothera marine assistant and dive team for assistance with collection and preservation of specimens.

\section{Compliance with ethical standards}

Conflict of interest The authors declare they have no conflict of interest.

Ethical approval All applicable institutional and/or national guidelines for the care and use of animals were followed and the necessary permits for collection of Antarctic animals obtained.

Open Access This article is distributed under the terms of the Creative Commons Attribution 4.0 International License (http://creat ivecommons.org/licenses/by/4.0/), which permits unrestricted use, distribution, and reproduction in any medium, provided you give appropriate credit to the original author(s) and the source, provide a link to the Creative Commons license, and indicate if changes were made.

\section{References}

Agresti A (2007) An introduction to categorical data analysis, 2nd edn. Wiley, Hoboken

Ahn IY, Surh J, Park YG et al (2003) Growth and seasonal energetics of the Antarctic bivalve Laternula elliptica from King George Island, Antarctica. Mar Ecol Prog Ser 257:99-110. https://doi. org/10.3354/meps257099

Allen JA (1978) Evolution of the Deep Sea protobranch bivalves. Philos Trans R Soc B Biol Sci 284:387-401. https://doi.org/10.1098/ rstb.1978.0076

Aronson RB, Thatje S, Clarke A et al (2007) Climate change and invasibility of the Antarctic benthos. Annu Rev Ecol Evol Syst 38:129-154. https://doi.org/10.1146/annurev.ecolsys.38.09120 6.095525

Barnes DKA (2016) Iceberg killing fields limit huge potential for benthic blue carbon in Antarctic shallows. Glob Chang Biol. https:// doi.org/10.1111/gcb.13523

Barnes DKA, Conlan KE (2007) Disturbance, colonization and development of Antarctic benthic communities. Phil Trans R Soc B 362:11-38

Barnes DKA, Souster T (2011) Reduced survival of Antarctic benthos linked to climate-induced iceberg scouring. Nat Clim Chang $1: 365-368$

Berkman PA, Cattaneo-Vietti R, Chiantore M, Howard-Williams C (2004) Polar emergence and the influence of increased sea-ice extent on the Cenozoic biogeography of pectinid molluscs in Antarctic coastal areas. Deep Sea Res Part II 51:1839-1855. https:// doi.org/10.1016/j.dsr2.2004.07.017

Bosch I, Pearse JS (1990) Developmental types of shallow-water asteroids of McMurdo Sound, Antarctica. Mar Biol 104:41-46. https ://doi.org/10.1007/BF01313155

Bowden DA (2005) Seasonality of recruitment in Antarctic sessile marine benthos. Mar Ecol Prog Ser 297:101-118. https://doi. org/10.3354/meps297101

Bowden DA, Clarke A, Peck LS (2009) Seasonal variation in the diversity and abundance of pelagic larvae of Antarctic marine invertebrates. Mar Biol 156:2033-2047. https://doi.org/10.1007/ s00227-009-1235-9

Brey T, Hain S (1992) Growth, reproduction and production of Lissarca notorcadensis (Bivalvia: philobryidae) in the Weddell Sea, Antarctica. Mar Ecol Prog Ser 82:219-226

Brey T, Dahm C, Gorny M et al (1996) Do Antarctic benthic invertebrates show an extended level of eurybathy? Antarct Sci 8:3-6. https://doi.org/10.1017/S0954102096000028

Brockington S, Peck LS, Tyler PA (2007) Gametogenesis and gonad mass cycles in the common circumpolar Antarctic echinoid Sterechinus neumayeri. Mar Ecol Prog Ser 330:139-147. https://doi. org/10.3354/meps330139

Byrne M (2011) Impact of ocean warming and ocean acidification on marine invertebrate life history stages: vulnerabilities and potential for persistence in a changing ocean. Oceanogr Mar Biol 49:1-42. https://doi.org/10.1016/j.marenvres.2011.10.00

Carter JG, Campbell DC, Campbell MR (2000) Cladistic perspectives on early bivalve evolution. Geol Soc Lond Spec Publ 177:47-79. https://doi.org/10.1144/GSL.SP.2000.177.01.04

Chiantore M, Cattaneo-Vietti R, Berkman PA et al (2001) Antarctic scallop (Adamussium colbecki) spatial population variability along the Victoria Land Coast, Antarctica. Polar Biol 24:139-143. https://doi.org/10.1007/s003000000191 
Chiantore M, Cattaneo-Vietti R, Elia L et al (2002) Reproduction and condition of the scallop Adamussium colbecki (Smith 1902), the sea-urchin Sterechinus neumayeri (Meissner 1900) and the seastar Odontaster validus Koehler 1911 at Terra Nova Bay (Ross Sea): different strategies related to inter-annual variations in food availability. Polar Biol 25:251-255. https://doi.org/10.1007/s0030 0-001-0331-1

Clark GF, Raymond B, Riddle MJ et al (2015) Vulnerability of Antarctic shallow invertebrate-dominated ecosystems. Austral Ecol 40:482-491. https://doi.org/10.1111/aec.12237

Clark MS, Sommer U, Sihra JK et al (2016) Biodiversity in marine invertebrate responses to acute warming revealed by a comparative multi-omics approach. Glob Chang Biol 23:318-330. https:// doi.org/10.1111/gcb.13357

Clarke A (1979) On living in cold water: k-strategies in antarctic benthos. Mar Biol 55:111-119. https://doi.org/10.1007/BF00397306

Clarke A (1988) Seasonality in the Antarctic marine environment. Comp Biochem Physiol Part B Comp Biochem 90:461-473. https ://doi.org/10.1016/0305-0491(88)90284-2

Clarke A, Meredith MP, Wallace MI et al (2008) Seasonal and interannual variability in temperature, chlorophyll and macronutrients in northern Marguerite Bay, Antarctica. Deep Sea Res Part II 55:1988-2006. https://doi.org/10.1016/j.dsr2.2008.04.035

Cohen J (1988) Statistical power analysis for the behavioural sciences, 2nd edn. Psychology Press, New York

Corbisier TN, Petti MAV, Skowronski RSP, Brito TAS (2004) Trophic relationships in the nearshore zone of Martel Inlet (King George Island, Antarctica): $\delta 13 \mathrm{C}$ stable-isotope analysis. Polar Biol 27:75-82. https://doi.org/10.1007/s00300-003-0567-z

Cripps GC, Priddle J (1995) Hydrocarbon content of an Antarctic infaunal bivalve - historical record or life cycle change? Antarct Sci 7:127-136. https://doi.org/10.1017/S0954102095000186

Davenport J (1988) The feeding mechanism of Yoldia (=Aequiyoldia) eightsi (Courthouy). Proc Biol Sci 232:431-442. https://doi. org/10.1098/rspb.1988.0005

De Broyer C, Danis B (2011) How many species in the Southern Ocean? Towards a dynamic inventory of the Antarctic marine species. Deep Sea Res Part II 58:5-17. https://doi.org/10.1016/j. dsr2.2010.10.007

Dell RK (1990) Antarctic Mollusca. Bull R Soc New Zeal 27:1-311

Fattorini D, Notti A, Nigro M, Regoli F (2010) Hyperaccumulation of vanadium in the Antarctic polychaete Perkinsiana littoralis as a natural chemical defense against predation. Environ Sci Pollut Res 17:220-228. https://doi.org/10.1007/s11356-009-0243-0

González-Wevar CA, Díaz A, Gerard K et al (2012) Divergence time estimations and contrasting patterns of genetic diversity between Antarctic and southern South America benthic invertebrates. Rev Chil Hist Nat 85:445-456

Grange LJ, Tyler PA, Peck LS, Cornelius N (2004) Long-term interannual cycles of the gametogenic ecology of the Antarctic brittle star Ophionotus victoriae. Mar Ecol Prog Ser 278:141-155. https:// doi.org/10.3354/meps278141

Grange LJ, Tyler PA, Peck LS (2007) Multi-year observations on the gametogenic ecology of the Antarctic seastar Odontaster validus. Mar Biol 153:15-23. https://doi.org/10.1007/s00227-007-0776-z

Grange LJ, Peck LS, Tyler PA (2011) Reproductive ecology of the circumpolar Antarctic nemertean Parborlasia corrugatus: no evidence for inter-annual variation. J Exp Mar Bio Ecol 404:98-107. https://doi.org/10.1016/j.jembe.2011.04.011

Gustafson RG, Reid RGB (1986) Development of the pericalymma larva of Solemya reidi (Bivalvia: cryptodonta: Solemyidae) as revealed by light and electron microscopy. Mar Biol 93:411-427. https://doi.org/10.1007/BF00401109

Heywood KJ, Sunke S, Heuzé C et al (2014) Ocean processes at the Antarctic continental slope. Phil Trans R Soc A 372:20130047. https://doi.org/10.1098/rsta.2013.0047
Higgs ND, Reed AJ, Hooke R et al (2009) Growth and reproduction in the Antarctic brooding bivalve Adacnarca nitens (Philobryidae) from the Ross Sea. Mar Biol 156:1073-1081. https://doi. org/10.1007/s00227-009-1154-9

Jaramillo JR, Thompson RJ (2008) The reproductive response of the protobranch bivalve Yoldia hyperborea to an intermittent influx of phytodetritus. An experimental approach. J Exp Mar Bio Ecol 357:57-63. https://doi.org/10.1016/j.jembe.2007.12.027

Kang DH, Ahn IY, Choi KS (2009) The annual reproductive pattern of the Antarctic clam, Laternula elliptica from Marian Cove, King George Island. Polar Biol 32:517-528. https://doi.org/10.1007/ s00300-008-0544-7

Lester SE, Gaines SD, Kinlan BP (2007) Reproduction on the edge: large-scale patterns of individual performance in a marine invertebrate. Ecology 88:2229-2239. https://doi.org/10.1890/06-1784.1

Mayewski PA, Meredith MP, Summerhayes CP et al (2009) State of the Antarctic and Southern Ocean climate system. Rev Geophys. https://doi.org/10.1029/2007RG000231

McClintock JB, Pearse JS (1986) Organic and energetic content of eggs and juveniles of antarctic echinoids and asteroids with lecithotrophic development. Comp Biochem Physiol Part A Physiol 85:341-345. https://doi.org/10.1016/0300-9629(86)90259-8

McClintock JB, Angus RA, Mcdonald MR et al (2009) Rapid dissolution of shells of weakly calcified Antarctic benthic macroorganisms indicates high vulnerability to ocean acidification. Antarct Sci 21:449. https://doi.org/10.1017/S0954102009990198

Meredith MP, King JC (2005) Rapid climate change in the ocean west of the Antarctic Peninsula during the second half of the 20th century. Geophys Res Lett 32:1-5. https://doi.org/10.1029/2005G L024042

Moran AL, McAlister JS (2009) Egg size as a life history character of marine invertebrates: is it all it's cracked up to be? Biol Bull 216:226-242. https://doi.org/10.1086/BBLv216n3p226

Morse MP, Zardus JD (1997) Bivalvia. In: Harrison FW, Kohn AJ (eds) Microscopic anatomy of invertebrates, vol 6A. Mollusca II. Wiley-Liss Inc, New York, pp 7-118

Nakaoka M (1994) Size-dependent reproductive traits of Yoldia notabilis (Bivalvia: protobranchia). Mar Ecol Prog Ser 114:129-138

Orejas C, Gili JM, López-González PJ et al (2007) Reproduction patterns of four Antarctic octocorals in the Weddell Sea: an inter-specific, shape, and latitudinal comparison. Mar Biol 150:551-563. https://doi.org/10.1007/s00227-006-0370-9

Orejas C, López-González P, Gili J et al (2012) Distribution and reproductive ecology of the Antarctic octocoral Ainigmaptilon antarcticum in the Weddell Sea. Mar Ecol Prog Ser 231:101-114. https:// doi.org/10.3354/meps231101

Pasotti F, Manini E, Giovannelli D et al (2015a) Antarctic shallow water benthos in an area of recent rapid glacier retreat. Mar Ecol 36:716-733. https://doi.org/10.1111/maec.12179

Pasotti F, Saravia LA, De Troch M et al (2015b) Benthic trophic interactions in an Antarctic shallow water ecosystem affected by recent glacier retreat. PLoS ONE 10:e0141742. https://doi.org/10.1371/ journal.pone. 0141742

Pearse JS (1965) Reproductive periodicities in several contrasting populations of Odontaster validus Koehler, a common Antarctic asteroid. Antarct Res Ser 5:39-85

Pearse JS, Lockhart SJ (2004) Reproduction in cold water: paradigm changes in the 20th century and a role for cidaroid sea urchins. Deep Sea Res Part II 51:1533-1549. https://doi.org/10.1016/j. dsr2.2004.06.023

Pearse JS, Mooi R, Lockhart SJ, Brandt A (2009) Brooding and species diversity in the Southern Ocean: selection for brooders or speciation within brooding clades. In: Krupnik I, Lang MA, Miller SE (eds) Smithsonian at the poles: contributions to international polar year science. Proceedings of the Smithsonian at the Poles Symposium, Smithsonian Institution Scholarly Press, pp 181-196 
Peck LS, Bullough LW (1993) Growth and population structure in the infaunal bivalve Yoldia eightsi in relation to iceberg activity at Signy Island, Antarctica. Mar Biol 117:235-241. https://doi. org/10.1007/BF00345668

Peck LS, Conway LZ (2000) The myth of metabolic cold adaptation: oxygen consumption in stenothermal Antarctic bivalves. Evol Biol Bivalvia 177:441-450. https://doi.org/10.1144/Gsl. Sp.2000.177.01.29

Peck LS, Colman JG, Murray AWA (2000) Growth and tissue mass cycles in the infaunal bivalve Yoldia eightsi at Signy Island, Antarctica. Polar Biol 23:420-428. https://doi.org/10.1007/s0030 00050463

Peck LS, Webb KE, Bailey DM (2004a) Extreme sensitivity of biological function to temperature in Antarctic marine species. Funct Ecol 18:625-630

Peck LS, Ansell AD, Webb KE et al (2004b) Movements and burrowing activity in the Antarctic bivalve molluscs Laternula elliptica and Yoldia eightsi. Polar Biol 27:357-367. https://doi. org/10.1007/s00300-003-0588-7

Peck LS, Convey P, Barnes DKA (2005) Environmental constraints on life histories in Antarctic ecosystems: tempos, timings and predictability. Biol Rev 81:75. https://doi.org/10.1017/S146479310 5006871

Peck LS, Clark MS, Morley SA et al (2009) Animal temperature limits and ecological relevance: effects of size, activity and rates of change. Funct Ecol 23:248-256. https://doi.org/10.111 $1 / \mathrm{j} .1365-2435.2008 .01537 . x$

Peck LS, Morley SA, Clark MS (2010) Poor acclimation capacities in Antarctic marine ectotherms. Mar Biol 157:2051-2059. https:// doi.org/10.1007/s00227-010-1473-x

Peck LS, Morley SA, Richard J et al (2014) Acclimation and thermal tolerance in Antarctic marine ectotherms. J Exp Biol 217:16-22. https://doi.org/10.1242/jeb.089946

Pörtner HO, Peck LS, Somero G (2007) Thermal limits and adaptation in marine Antarctic ectotherms: and integrative view. Phil Trans R Soc B 362:2233-2258

Ramirez-Llodra E (2002) Fecundity and life-history strategies in marine invertebrates. Adv Mar Biol 43:87-170. https://doi. org/10.1016/S0065-2881(02)43004-0

Rasband WS (1997-2016) ImageJ, U.S. National Institutes of Health, Bathesda, Maryland, USA, http://imagej.nih.gov/ij/

Reed AJ, Thatje S, Linse K (2013a) An unusual hermaphrodite reproductive trait in the Antarctic brooding bivalve Lissarca miliaris (Philobryidae) from the Scotia Sea, Southern Ocean. Polar Biol 36:1-11. https://doi.org/10.1007/s00300-012-1233-0

Reed AJ, Morris JP, Linse K, Thatje S (2013b) Plasticity in shell morphology and growth among deep-sea protobranch bivalves of the genus Yoldiella (Yoldiidae) from contrasting Southern Ocean regions. Deep Sea Res Part I 81:14-24. https://doi.org/10.1016/j. dsr.2013.07.006
Reed AJ, Morris JP, Linse K, Thatje S (2014) Reproductive morphology of the deep-sea protobranch bivalves Yoldiella ecaudata, Yoldiella sabrina, and Yoldiella valettei (Yoldiidae) from the Southern Ocean. Polar Biol 37:1383-1392. https://doi. org/10.1007/s00300-014-1528-4

Román-González A, Scourse JD, Butler PG et al (2017) Analysis of ontogenetic growth trends in two marine Antarctic bivalves Yoldia eightsi and Laternula elliptica: implications for sclerochronology. Palaeogeogr Palaeoclimatol Palaeoecol 465:300-306. https://doi. org/10.1016/j.palaeo.2016.05.004

Sahade R, Tatián M, Esnal G (2004) Reproductive ecology of the ascidian Cnemidocarpa verrucosa at Potter Cove, South Shetland Islands, Antarctica. Mar Ecol Prog Ser 272:131-140. https://doi. org/10.3354/meps272131

Sanford E, Kelly MW (2011) Local adaptation in marine invertebrates. Ann Rev Mar Sci 3:509-537. https://doi.org/10.1146/annurevmarine-120709-142756

Scheltema RS, Williams IP (2009) Reproduction among protobranch bivalves of the family Nuculidae from sublittoral, bathyal, and abyssal depths off the New England coast of North America. Deep Sea Res Part II 56:1835-1846. https://doi.org/10.1016/j. dsr2.2009.05.024

Servetto N, Sahade R (2016) Reproductive Seasonality of the Antarctic Sea Pen Malacobelemnon daytoni (Octocorallia, Pennatulacea, Kophobelemnidae). PLoS ONE 11:e0163152. https://doi. org/10.1371/journal.pone.0163152

Sharma PP, Zardus JD, Boyle EE et al (2013) Into the deep: a phylogenetic approach to the bivalve subclass protobranchia. Mol Phylogenet Evol 69:188-204. https://doi.org/10.1016/j.ympev .2013.05.018

Stanwell-Smith D, Peck LS, Clarke A et al (1999) The distribution, abundance and seasonality of pelagic marine invertebrate larvae in the maritime Antarctic. Philos Trans R Soc B Biol Sci 354:471484. https://doi.org/10.1098/rstb.1999.0398

Strugnell JM, Cherel Y, Cooke IR et al (2011) The Southern Ocean: source and sink? Deep Sea Res Part II 58:196-204. https://doi. org/10.1016/j.dsr2.2010.05.015

Tyler PA, Harvey R, Giles LA, Gage JD (1992) Reproductive strategies and diet in deep-sea nuculanid protobranchs (Bivalvia: nuculoidea) from the rockall trough. Mar Biol 114:571-580. https:// doi.org/10.1007/BF00357254

Tyler PA, Reeves S, Peck L et al (2003) Seasonal variation in the gametogenic ecology of the Antarctic scallop Adamussium colbecki. Polar Biol 26:727-733. https://doi.org/10.1007/s0030 $0-003-0548-2$

Zardus JD (2002) Protobranch bivalves. Adv Mar Biol 42:1-65. https ://doi.org/10.1016/S0065-2881(02)42012-3

Zardus JD, Morse MP (1998) Embryogenesis, morphology and ultrastructure of the pericalymma larva of Acila castrensis (Bivalvia: protobranchia: Nuculoida). Invert Biol 117(3):221-244 